\title{
PERCEPTIONS OF PARENTS AND LEARNERS TO MODULAR DISTANCE LEARNING AS CONTEMPORARY TEACHING STRATEGY
}

\author{
Emma S. Trovela \\ Faculty, Sta. Catalina Integrated National High School
}

Article DOI: https://doi.org/10.36713/epra7330

DOI No: 10.36713/epra7330

\begin{abstract}
This research investigated the parents and learners' perceptions on modular distance learning that they are experiencing during this time of pandemic as part contemporary new normal education setup. The main purpose of this study was to understand parents' and learners' perceptions on modular distance learning as contemporary teaching strategy and how they coped with the experiences and challenges of the new normal education settings. The participants of this study where five (5) senior high school learners and five (5) parents/guardians of senior high school learners of Sta. Catalina Integrated National High School. The research was conducted in Majayjay District from School Year 2020-2021.

This study used Qualitative Research through Descriptive research where in-depth interviewing and storytelling was done to gather the narratives or accounts of the research participants. Using an interview protocol and with a strong collaboration with the participants, the researcher will manage all the fieldwork and ensured the depth and breadth of the study. Through the analysis of the data from the interview, the Perception of Parents and Learners on Modular Distance learning as contemporary teaching strategy shows effectiveness even facing different challenges and disadvantage.
\end{abstract}

KEYWORDS: Modular Distance Learning, Self-Learning Modules, Edutainment, Academic Performance, Conceptual Understanding

\section{INTRODUCTION}

In order to enhance the educational experience of learners, it would seem that the majority of educational institutions in the Philippines have committed strategically to a greater use of modular distance learning and e-learning. Alongside, broad commitments to flexible delivery, student-centered learning approaches and the development of desired attributes of student learning can be found in institutional plans and policies. The purpose of teaching is learning. A classroom teacher only teaches what he or she considers important and difficult in the lecture. They have neither the time nor the energy to teach everything. However, learners want and need to know everything. To paraphrase the old saying, we should be teaching them 'fishing' not giving them a 'fish'. Educators should encourage learners to become active and lifelong learners. Teachers need to focus on learners' characteristics and their learning styles. When a teacher prepares a lecture, he or she needs to understand what learners want to know and what they need to know.

Despite the small differences in organization, pedagogical approaches and contemporary teaching strategies, the world experiences are quite similar in general terms. This allows us outlining the main features and advantages of distance learning. Distance learning allows learners, who do not have the 


\section{EPRA International Journal of Research and Development (IJRD)

opportunity to attend school for obvious reasons, to get content knowledge at full scale. Distance learning can follow both a special program and a general school curriculum. Distance learning requires the learner and the teacher to have a sufficient level of proficiency. Any learner must have a tutor to learn at distance. In most cases, tutor's role is played by a parent, who also goes between the learner and the teacher. Distance learning can take a hybrid shape (include some elements of full-time education) or be completely virtual. Distance learning should have a good legal framework behind it.

Distance learning is not just the only opportunity for some groups of learners. In cases when the learner is not comfortable with group lessons, online learning contributes to greater interest in learning and to better performance (Ma \& Wei, 2016). Student's need in communication with the teacher sets a shape for new curricula to take.

Given the abovementioned, this research will investigate the parents and learners' perceptions on modular distance learning that they are experiencing during this time of pandemic as part new normal education setup.

\section{OBJECTIVE OF THE STUDY}

The main purpose of this research is to understand parents' and learners' perceptions on modular distance learning as contemporary teaching strategy and how they coped with the experiences and challenges of the new normal education settings.

Distinctively, it sought to answer the subsequent questions:

1. What perceptions do parents and learners have regarding the modular distance learning as contemporary teaching strategy?

2. How do participants described their teaching and learning experiences under the new normal education?

- Experiences of Parents and Learners on Modular Distance Learning

- Contribution for Growth and Development

- Strategies used by the Parents to guide students in answering modules.

- Challenges encountered by the Parents and Learner.

3. Based on the findings of the study, what intervention can be proposed?

\section{RELATED LITERATURE}

The Philippine Education Quarterly (1985, as cited by Figuerres, 2014) reported that modules can take the place of a teacher. These self-learning devices help pupils to learn or acquire skills, knowledge and information in the absence of a teacher. These materials provide sufficient reinforcement, enrichment and source materials. They allow also the learner to work at a rate style and level situated to his capacity. Among the forms of individualized instruction, modules are effective and economical in developing specific knowledge and skills. Modules induce learning with minimum teacher direction and supervision. Furthermore, these develop learning and grading strategies, improve classroom management techniques, and encourage achievement for greater use of existing educational resources through the establishment of realistic obtainable learning goals within an individualized program of studies.

Figuerres (2014) a module is a self-contained, independent unit of instruction prepared for the purpose of attaining specific instructional objectives. It is characteristically self-directing since it includes instructions on how the various investigation will be pursued also included is a listing of the materials and other resources that should accompany the text of the module. Classroom instruction using modules is described as self-pacing where the pupil progress through the learning tasks at his own rate.

According to Salandanan (2019), selfinstructional materials are those which are described to be self-contained and the manner of presentation is such that the learning activities can be undertaken individually or in small groups. These materials are most effectively used in individualized instruction programs. The self-instructional module helps in providing remedial instruction for slow learners and enrichment materials for fast learners. Topics can best be presented through these self-instructional materials.

Aquino-Danganan (2011) proposed instructional modules in developing computational skills in College Algebra. She mentioned that the proposed instructional modules had titles, instruction to the learners, rationale, objectives, pretest with answer keys, worksheet assignment, progress check with answer key and posttest with answer key. The format and language of each were properly organized, clear and simple. The objectives of each module were specific and were based on the course syllabus. The topics were properly developed and explained and the activities and exercises facilitated student learning in College Algebra.

LeBrun (2011) each module has a distinct training element; it covers either a single element of subject matter content or a group of content elements objectives; preferably in behavioral form Rudnitsky 


\section{EPRA International Journal of Research and Development (IJRD)}

(2011) A recognized level of proficiency or a qualification can be achieved through the completion of a series of modules. LeBrun (2011) also stated that when vendors sell individualized instructional modules "the ability to manage the classroom" was mentioned frequently. Rudnitsky (2011) found that using individualized instructional modules reduces the time it takes teachers to develop a technology-based program.

\section{RESULTS AND DISCUSSION}

Perceptions of Parents and Learners regarding the Modular Distance Learning as Contemporary Teaching Strategy

\begin{tabular}{|c|c|c|c|c|c|}
\hline \multirow[t]{2}{*}{ QUESTIONS } & \multirow[t]{2}{*}{ RAW DATA (RESPONSES/ANSWERS) } & \multirow{2}{*}{$\begin{array}{l}\text { PARTIC } \\
\text { IPANTS }\end{array}$} & \multicolumn{2}{|c|}{ PRELIMINARY CODES } & \multirow[t]{2}{*}{ THEMES } \\
\hline & & & $\begin{array}{l}\text { COMMON } \\
\text { ALITIES }\end{array}$ & CATEGORIES & \\
\hline \multirow{5}{*}{$\begin{array}{l}\text { 2.2. What can } \\
\text { you say } \\
\text { about this } \\
\text { new normal } \\
\text { education } \\
\text { setup? }\end{array}$} & $\begin{array}{l}\text { As of now, that is what really, we should } \\
\text { do for the safety of everyone. Face to } \\
\text { face should not be allowed because of } \\
\text { the pandemic. }\end{array}$ & P-P 1 & \multirow{5}{*}{\multicolumn{2}{|c|}{$\begin{array}{l}\text { Challenges in the New } \\
\text { Normal Educational } \\
\text { Setup }\end{array}$}} & \multirow{5}{*}{$\begin{array}{l}\text { Parents' } \\
\text { Perception } \\
\text { s on MDL }\end{array}$} \\
\hline & $\begin{array}{l}\text { It is quite difficult in the aspect of } \\
\text { education, because not everyone has the } \\
\text { access of internet, and not all the } \\
\text { answer are written in the module. }\end{array}$ & P-P 2 & & & \\
\hline & $\begin{array}{l}\text { Quite difficult ma'am, difficult in the } \\
\text { part of the student and the teacher, as a } \\
\text { student their lesson is very different } \\
\text { compare to the past. That is why when } \\
\text { my sister asks regarding her lesson, I'll } \\
\text { just tell that just search it in the } \\
\text { internet. }\end{array}$ & P-P 3 & & & \\
\hline & $\begin{array}{l}\text { So far, I can say that modular distance } \\
\text { learning is quite okay, my sister learned } \\
\text { and her mind sharpened because it is } \\
\text { more on self-study. }\end{array}$ & P-P 4 & & & \\
\hline & Very hard the child learned nothing & P-P 5 & & & \\
\hline
\end{tabular}

\section{Table 1. Parents' Perception on Modular Distance Learning}

Upon analyzing the responded provided by the parentparticipants, it can be inferred that their perception on the modular distance learning poses challenges as supported by their answers that it is quite difficult for them in the aspect of Education because of the challenges in the access of internet, all of the answers are not written in the answer key of modules, and their lessons are different from the past. From the commonalities and categories, it falls as a challenge in the New Normal Educational Setup.

Table 2. Learners' Perception on Modular Distance Learning

\begin{tabular}{|c|c|c|c|c|c|}
\hline \multirow[t]{2}{*}{ QUESTIONS } & \multirow[t]{2}{*}{ RAW DATA (RESPONSES/ANSWERS) } & \multirow[t]{2}{*}{$\begin{array}{l}\text { PARTICIP } \\
\text { ANTS }\end{array}$} & \multicolumn{2}{|c|}{$\begin{array}{l}\text { PRELIMINARY } \\
\text { CODES }\end{array}$} & \multirow[t]{2}{*}{ THEMES } \\
\hline & & & $\begin{array}{l}\text { COMMO } \\
\text { NALITIES }\end{array}$ & $\begin{array}{l}\text { CATEG } \\
\text { ORIES }\end{array}$ & \\
\hline \multirow{2}{*}{$\begin{array}{l}\text { 2.2. What } \\
\text { can you say } \\
\text { about this } \\
\text { new normal } \\
\text { education } \\
\text { setup? }\end{array}$} & $\begin{array}{l}\text { Quite difficult but we must think first of } \\
\text { our safety, we need to follow the } \\
\text { protocol of the government. There is } \\
\text { some adjustment on the part of the } \\
\text { teacher and the student. }\end{array}$ & S-P 1 & \multirow{2}{*}{\multicolumn{2}{|c|}{ Challenges of MDL }} & \multirow{2}{*}{$\begin{array}{l}\text { Learner's } \\
\text { Perceptions } \\
\text { on MDL }\end{array}$} \\
\hline & $\begin{array}{l}\text { Difficult, because this is new to us, } \\
\text { because of the pandemic, it is my first } \\
\text { time to study all by myself that is why } \\
\text { quite difficult. }\end{array}$ & S-P 2 & & & \\
\hline
\end{tabular}

(c) 2021 EPRA IJRD | Journal DOI: https://doi.org/10.36713/epra2016 | www.eprajournals.com |285 | 


\section{EPRA International Journal of Research and Development (IJRD)}

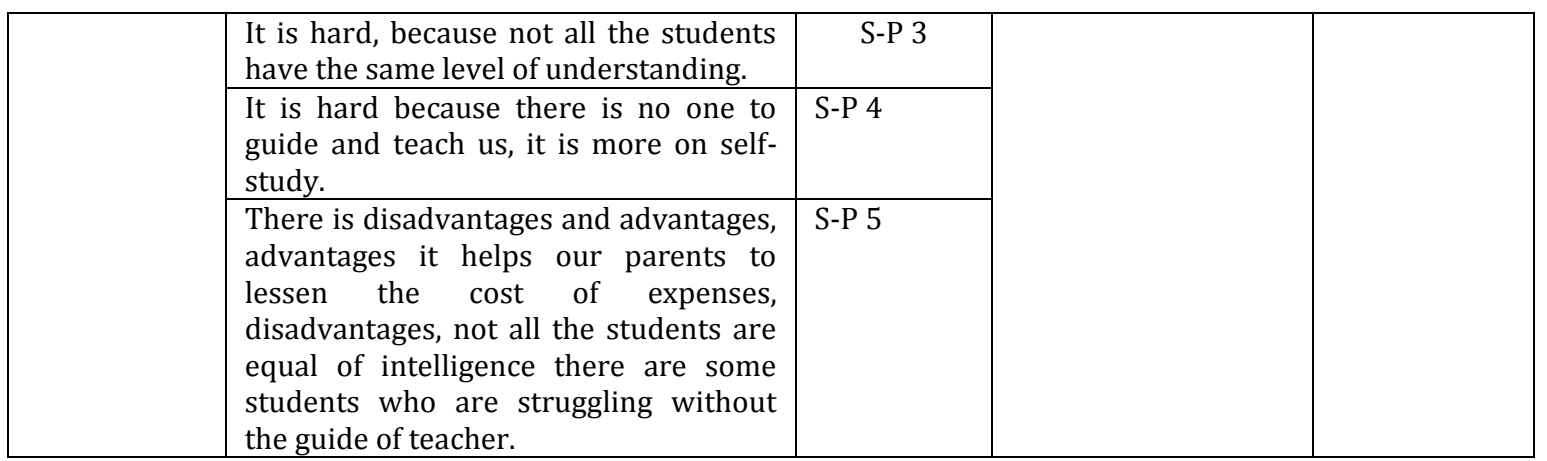

Examining the responses of learner participants, it can be inferred that their perceptions on Modular Distance Learning pose challenges and disadvantages. This can be supported by their answers that Modular Distance Learning is Quite difficult that the teachers and students' experiences adjustments in the implementation. Other reasons emerged includes learners do self-study and do not have the same level of understanding when it comes to the different lessons on modules. Aside from that, although there is cost-cutting to the side of parents since students are only studying at home, still, the respondents reiterated that not all students are equal in intelligence that results to struggling in studying without the physical guide of a teacher.

\begin{tabular}{|c|c|c|c|c|c|}
\hline \multirow[t]{2}{*}{ QUESTIONS } & \multirow[t]{2}{*}{ RAW DATA (RESPONSES/ANSWERS) } & \multirow{2}{*}{$\begin{array}{l}\text { PARTI } \\
\text { CIPAN } \\
\quad \text { TS }\end{array}$} & \multicolumn{2}{|c|}{$\begin{array}{l}\text { PRELIMINARY } \\
\text { CODES }\end{array}$} & \multirow[t]{2}{*}{ THEMES } \\
\hline & & & $\begin{array}{l}\text { COMMONA } \\
\text { LITIES }\end{array}$ & $\begin{array}{l}\text { CATEG } \\
\text { ORIES }\end{array}$ & \\
\hline \multirow{5}{*}{$\begin{array}{c}\text { 2.1. Can you } \\
\text { tell me } \\
\text { more about } \\
\text { your } \\
\text { understandi } \\
\text { ng on } \\
\text { Modular } \\
\text { Distance } \\
\text { Learning? }\end{array}$} & $\begin{array}{l}\text { Written works, most of the students do not } \\
\text { use internet connection }\end{array}$ & P-P 1 & \multirow{5}{*}{\multicolumn{2}{|c|}{$\begin{array}{l}\text { Module and Printed } \\
\text { Materials }\end{array}$}} & \multirow{5}{*}{$\begin{array}{l}\text { Parents' } \\
\text { Experien } \\
\text { ces on } \\
\text { MDL }\end{array}$} \\
\hline & $\begin{array}{l}\text { It is a way of studying where module is } \\
\text { used by the student to be able to study at } \\
\text { home }\end{array}$ & P-P 2 & & & \\
\hline & $\begin{array}{l}\text { What they are doing is taking the module at } \\
\text { school, then answer sheet will pass every } \\
\text { Friday. }\end{array}$ & P-P 3 & & & \\
\hline & $\begin{array}{l}\text { Printed materials that my sister will answer } \\
\text { at home. }\end{array}$ & P-P 4 & & & \\
\hline & $\begin{array}{l}\text { Studying at home similar to distance } \\
\text { learning. }\end{array}$ & P-P 5 & & & \\
\hline \multirow{5}{*}{$\begin{array}{l}\text { 3. Do your } \\
\text { child } \\
\text { accomplish } \\
\text { all the } \\
\text { learning } \\
\text { tasks on } \\
\text { his/her self- } \\
\text { learning } \\
\text { modules on } \\
\text { time? }\end{array}$} & $\begin{array}{l}\text { I think my daughter are able to answer all } \\
\text { the task because she can submit on time. }\end{array}$ & P-P 1 & & & \multirow{5}{*}{$\begin{array}{c}\text { Parents } \\
\text { as PARA- } \\
\text { TEACHE } \\
\text { RS } \\
\text { (facilitati } \\
\text { ng } \\
\text { learning) }\end{array}$} \\
\hline & Yes, able to accomplish all the task & P-P 2 & & & \\
\hline & Able to accomplish if she spent time on it. & P-P 3 & & & \\
\hline & $\begin{array}{l}\text { I think yes, she is able to answer the task, she } \\
\text { spent her time on reading and researching. }\end{array}$ & P-P 4 & & & \\
\hline & I think she's able to accomplish the task. & P-P 5 & & & \\
\hline
\end{tabular}

Based on their responses, it can be inferred that the parent-participants' understanding of Modular Distance Learning is the use of Modules, mostly of
Written Works that learners will answer at Home. Also, with their responses, it shows that the given modules by teachers to learners gives them enough time to answer 


\section{EPRA International Journal of Research and Development (IJRD)

or complete the given modules for submission at specific time. Aside from that, it shows that the Parent's role based on the theme is that they serve as Para-Teachers (where they are helping in facilitating the learning with the learners in studying their modules.)

Table 4. Experiences of Learners on Modular Distance Learning

\begin{tabular}{|c|c|c|c|c|c|}
\hline \multirow[t]{2}{*}{ QUESTIONS } & \multirow{2}{*}{$\begin{array}{c}\text { RAW DATA } \\
\text { (RESPONSES/ANSWERS) }\end{array}$} & \multirow{2}{*}{$\begin{array}{l}\text { PARTICI } \\
\text { PANTS }\end{array}$} & \multicolumn{2}{|c|}{ PRELIMINARY CODES } & \multirow[t]{2}{*}{ THEMES } \\
\hline & & & $\begin{array}{l}\text { COMMONA } \\
\text { LITIES }\end{array}$ & $\begin{array}{c}\text { CATEGO } \\
\text { RIES }\end{array}$ & \\
\hline \multirow{5}{*}{$\begin{array}{l}\text { 2.1. Can you } \\
\text { tell me more } \\
\text { about your } \\
\text { understandin } \\
\text { g on Modular } \\
\text { Distance } \\
\text { Learning? }\end{array}$} & $\begin{array}{l}\text { The students will answer at home, } \\
\text { the parents take the module from } \\
\text { the school pass the answer sheet at } \\
\text { the school }\end{array}$ & S-P 1 & \multirow{5}{*}{\multicolumn{2}{|c|}{$\begin{array}{l}\text { Module and Printed } \\
\text { Materials }\end{array}$}} & \multirow{5}{*}{$\begin{array}{l}\text { Learner's } \\
\text { Experiences } \\
\text { on MDL }\end{array}$} \\
\hline & $\begin{array}{l}\text { The students answer at home and } \\
\text { the parents take the module from } \\
\text { the school. }\end{array}$ & S-P 2 & & & \\
\hline & $\begin{array}{l}\text { They will not use online, modular } \\
\text { lesson will be distributed by the } \\
\text { teachers through printed materials. }\end{array}$ & S-P 3 & & & \\
\hline & $\begin{array}{l}\text { In my own understanding, teacher } \\
\text { will be distributed printed materials } \\
\text { on different subjects and students } \\
\text { will answer it through writing on } \\
\text { yellow pad. }\end{array}$ & S-P 4 & & & \\
\hline & $\begin{array}{l}\text { It is not face to face, there is no } \\
\text { communication between the teacher } \\
\text { and the students, it is more on self- } \\
\text { studying while at home }\end{array}$ & S-P 5 & & & \\
\hline \multirow{5}{*}{$\begin{array}{c}\text { 3. Do you } \\
\text { accomplish } \\
\text { all the } \\
\text { learning } \\
\text { tasks on your } \\
\text { self-learning } \\
\text { modules on } \\
\text { time? }\end{array}$} & Yes & S-P 1 & & & \\
\hline & Yes & S-P 2 & & & \\
\hline & Yes, able to accomplish & S-P 3 & & & \\
\hline & yes & S-P 4 & & & \\
\hline & $\begin{array}{l}\text { Yes able to accomplish before the } \\
\text { deadline. }\end{array}$ & S-P 5 & & & \\
\hline \multirow{3}{*}{$\begin{array}{l}\text { 3.1. Do you } \\
\text { find it a time- } \\
\text { wasting } \\
\text { activity? }\end{array}$} & $\begin{array}{l}\text { No, as a student we need to stand on } \\
\text { our own without asking the help of } \\
\text { classmate, here we learn to answer } \\
\text { on our own. Understand the lesson } \\
\text { and instructions. I manage my time } \\
\text { very effectively by following the } \\
\text { WHLP given by my adviser so I can } \\
\text { utilize my time and balance my } \\
\text { household chores and my studies. }\end{array}$ & S-P 2 & \multirow{3}{*}{\multicolumn{2}{|c|}{$\begin{array}{l}\text { Time Management and } \\
\text { proper utilization of } \\
\text { the internet }\end{array}$}} & \multirow{3}{*}{ Edutainment } \\
\hline & $\begin{array}{l}\text { No, because I learn somehow. } \\
\text { Sometime, SLMs' are providing link } \\
\text { for videos, like educational video } \\
\text { that serves as an additional learning } \\
\text { material that we can use for } \\
\text { answering the different tasks on our } \\
\text { module. }\end{array}$ & S-P 3 & & & \\
\hline & $\begin{array}{l}\text { No. most of the time I enjoy learning } \\
\text { when SLMs are providing links to } \\
\text { watch. Those videos were very } \\
\text { helpful so I can easily understand } \\
\text { the lesson even without asking }\end{array}$ & S-P 4 & & & \\
\hline
\end{tabular}

(C) 2021 EPRA IJRD | Journal DOI: https://doi.org/10.36713/epra2016 | www.eprajournals.com |287 | 


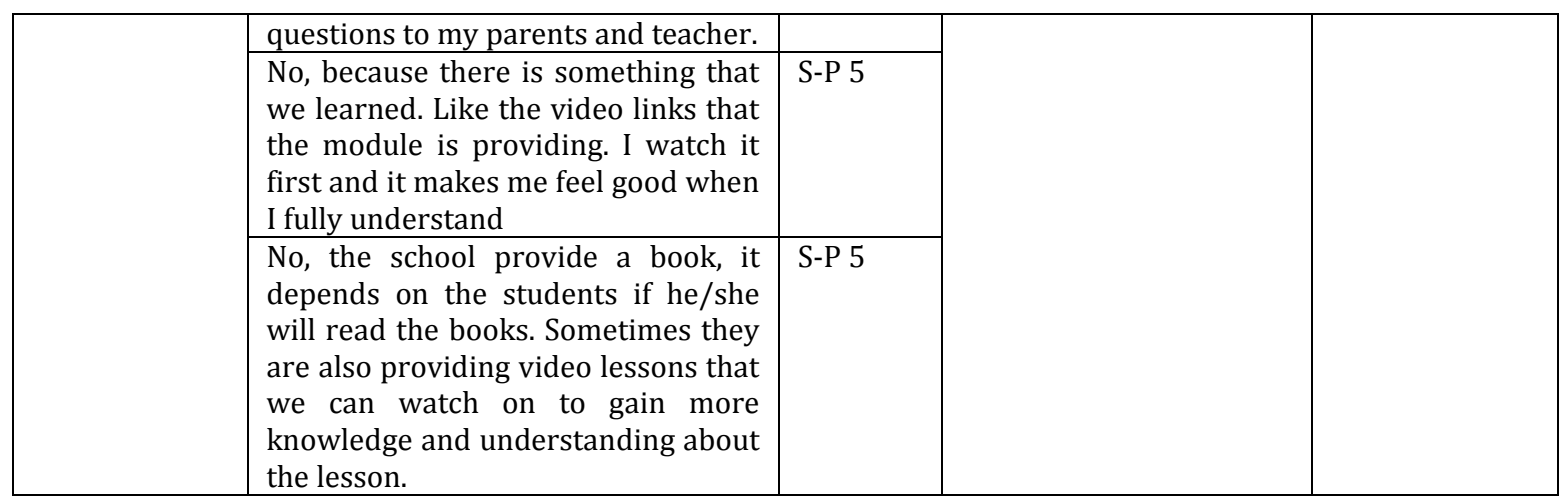

Based on their responses, most of the StudentParticipants see modular distance learning as not timewasting activity. From their responses, learners can learn something, and it gives them the independence of learning at their own pace. Also, there is still communication with the teachers since the learners are provided with the Weekly Home Learning Plan as well as additional educational video links that learners can access to support their learning that falls on the theme of "Edutainment."

\section{Contribution for Growth and Development}

Table 5. Parents Perception on Growth and Development on Learners

\begin{tabular}{|c|c|c|c|c|c|}
\hline \multirow[t]{2}{*}{ QUESTIONS } & \multirow[t]{2}{*}{ RAW DATA (RESPONSES/ANSWERS) } & \multirow[t]{2}{*}{$\begin{array}{l}\text { PARTICI } \\
\text { PANTS }\end{array}$} & \multicolumn{2}{|c|}{$\begin{array}{c}\text { PRELIMINARY } \\
\text { CODES }\end{array}$} & \multirow[t]{2}{*}{ THEMES } \\
\hline & & & $\begin{array}{c}\text { COMMO } \\
\text { NALITIES }\end{array}$ & $\begin{array}{l}\text { CATEG } \\
\text { ORIES }\end{array}$ & \\
\hline \multirow{5}{*}{$\begin{array}{l}\text { 2.3. Was it } \\
\text { helpful and } \\
\text { effective for } \\
\text { your growth } \\
\text { and } \\
\text { development } \\
\text { ? Why? }\end{array}$} & $\begin{array}{l}\text { I can say yes, Because they are the one } \\
\text { who answered their module, their ideas } \\
\text { and understandings becomes widened. }\end{array}$ & P-P 1 & \multirow{5}{*}{\multicolumn{2}{|c|}{$\begin{array}{l}\text { Monitoring of } \\
\text { Learning Tasks } \\
\text { (at home) }\end{array}$}} & \multirow{5}{*}{$\begin{array}{l}\text { Parents as } \\
\text { PARA- } \\
\text { TEACHERS } \\
\text { (facilitating } \\
\text { learning) }\end{array}$} \\
\hline & $\begin{array}{l}\text { Yes ma'am, she learned to answer the } \\
\text { task all by herself and it is also a practice } \\
\text { of self-control if she can answer honestly. }\end{array}$ & P-P 2 & & & \\
\hline & $\begin{array}{l}\text { I think it really helps, like now that we } \\
\text { are experiencing pandemic it is better to } \\
\text { study than doing nothing at home. }\end{array}$ & P-P 3 & & & \\
\hline & $\begin{array}{l}\text { I think it helps because there is additional } \\
\text { knowledge that she learned, like what } \\
\text { she said her English vocabulary was } \\
\text { enhanced. }\end{array}$ & P-P 4 & & & \\
\hline & $\begin{array}{l}\text { I think it developed somehow because } \\
\text { they will be able to answer with their } \\
\text { own idea. }\end{array}$ & P-P 5 & & & \\
\hline
\end{tabular}

From the responses, it can be deduced that the ParentParticipants take it in a positive side that their sons/daughters pose Growth and development in the implementation of the Modular Distance learning. This is supported by their responses that the learners are the one who answers their modules using only their own ideas and understanding. It also imposes self-control in answering the modules honestly. This falls on the category of Monitoring of Learning task (at home) where the parents serve as facilitator. 


\section{EPRA International Journal of Research and Development (IJRD)}

Volume: 6 | Issue: 6 | June 2021

- Peer Reviewed Journal

Table 6. Learners' Perception on Growth and Development

\begin{tabular}{|c|c|c|c|c|c|}
\hline \multirow[t]{2}{*}{ QUESTIONS } & \multirow[t]{2}{*}{ RAW DATA (RESPONSES/ANSWERS) } & \multirow[t]{2}{*}{$\begin{array}{l}\text { PARTIC } \\
\text { IPANTS }\end{array}$} & \multicolumn{2}{|c|}{$\begin{array}{l}\text { PRELIMINARY } \\
\text { CODES }\end{array}$} & \multirow[t]{2}{*}{ THEMES } \\
\hline & & & $\begin{array}{l}\text { COMMON } \\
\text { ALITIES }\end{array}$ & $\begin{array}{l}\text { CATEG } \\
\text { ORIES }\end{array}$ & \\
\hline \multirow{5}{*}{$\begin{array}{l}\text { 2.3. Was it } \\
\text { helpful and } \\
\text { effective for } \\
\text { your growth } \\
\text { and } \\
\text { development } \\
\text { ? Why? }\end{array}$} & $\begin{array}{l}\text { Yes, because it is one way to test our self- } \\
\text { comprehension, like in reading instructions } \\
\text { you can test yourself if you understand it, or } \\
\text { you can ask the help of your parent but in } \\
\text { answering the question it should be your own } \\
\text { idea. }\end{array}$ & S-P 1 & \multirow{5}{*}{\multicolumn{2}{|c|}{$\begin{array}{c}\text { Monitoring } \\
\text { (Learning by doing) } \\
\text { Learning } \\
\text { Independently }\end{array}$}} & \multirow{5}{*}{$\begin{array}{l}\text { Acquisiti } \\
\text { on of } \\
\text { Knowled } \\
\text { ge }\end{array}$} \\
\hline & $\begin{array}{l}\text { Yes it helps me to develop myself because I } \\
\text { learned to answer on my own, without the } \\
\text { help of my classmate and teacher. }\end{array}$ & S-P 2 & & & \\
\hline & $\begin{array}{l}\text { I can say because I was able to manage my } \\
\text { time then I just think that I need to study } \\
\text { more. }\end{array}$ & S-P 3 & & & \\
\hline & $\begin{array}{l}\text { Yes it helps me to develop myself without } \\
\text { asking the help of others. }\end{array}$ & S-P 4 & & & \\
\hline & $\begin{array}{l}\text { For me yes, it helps develop myself, there is } \\
\text { improvement, I learned in this situation. }\end{array}$ & S-P 5 & & & \\
\hline
\end{tabular}

From the given responses, it may be inferred that there is improvement in the Growth and development of Learners in the implementation of Modular Distance Learning. This is supported by their responses that it tested their self-comprehension, able to manage their own time in answering the modules provoking their own thinking to finish the modules. Although there is the guidance of the parents, still learners were able to self-study and improve themselves by having independence on their study. This falls on the theme of Acquisition of Knowledge through learning independently.

\begin{tabular}{|c|c|c|c|c|c|}
\hline \multirow[t]{2}{*}{ QUESTIONS } & \multirow[t]{2}{*}{ RAW DATA (RESPONSES/ANSWERS) } & \multirow{2}{*}{$\begin{array}{l}\text { PARTI } \\
\text { CIPAN } \\
\text { TS }\end{array}$} & \multicolumn{2}{|c|}{$\begin{array}{l}\text { PRELIMINARY } \\
\text { CODES }\end{array}$} & \multirow[t]{2}{*}{ THEMES } \\
\hline & & & $\begin{array}{l}\text { COMMO } \\
\text { NALITIES }\end{array}$ & $\begin{array}{l}\text { CATEG } \\
\text { ORIES }\end{array}$ & \\
\hline \multirow{5}{*}{$\begin{array}{l}\text { 3.3. How do } \\
\text { you motivate } \\
\text { yourself to } \\
\text { accomplish all } \\
\text { the tasks? Can } \\
\text { you tell me } \\
\text { more? }\end{array}$} & $\begin{array}{l}\text { Sometimes I remind her the deadline of } \\
\text { submission, so she needs to accomplish her } \\
\text { module }\end{array}$ & P-P 1 & \multirow{5}{*}{\multicolumn{2}{|c|}{ MDL's Challenges }} & \multirow{5}{*}{$\begin{array}{c}\text { Parents as } \\
\text { PARA- } \\
\text { TEACHERS } \\
\text { (facilitating } \\
\text { learning) }\end{array}$} \\
\hline & $\begin{array}{l}\text { To be able to answer her module, I'll explain to } \\
\text { her the part of the lesson that are not clear to } \\
\text { her. }\end{array}$ & P-P 2 & & & \\
\hline & $\begin{array}{l}\text { I'll give her enough time to be able to answer } \\
\text { the whole learning task. }\end{array}$ & P-P 3 & & & \\
\hline & We guide her and help her as long as we can. & P-P 4 & & & \\
\hline & $\begin{array}{l}\text { I looked at her lesson if I could answer it then I } \\
\text { help her. }\end{array}$ & P-P 5 & & & \\
\hline \multirow{5}{*}{$\begin{array}{l}\text { 4. Can you tell } \\
\text { me that you } \\
\text { are learning } \\
\text { from these } \\
\text { self-leaning } \\
\text { modules? Why } \\
\text { do you say so? }\end{array}$} & $\begin{array}{l}\text { Yes she learned, sometimes I was beside her } \\
\text { when she's answering the module }\end{array}$ & P-P 1 & \multirow{5}{*}{\multicolumn{2}{|c|}{$\begin{array}{l}\text { Effectiveness of } \\
\text { MDL }\end{array}$}} & \multirow{5}{*}{$\begin{array}{c}\text { Parents as } \\
\text { PARA- } \\
\text { TEACHERS } \\
\text { (facilitating } \\
\text { learning) }\end{array}$} \\
\hline & $\begin{array}{l}\text { Yes ma'am, if you understand the question, you } \\
\text { will understand the lesson that is being given. }\end{array}$ & P-P 2 & & & \\
\hline & Yes, she learned with the help of internet. & P-P 3 & & & \\
\hline & $\begin{array}{l}\text { Yes, I can say that there is additional knowledge } \\
\text { she can study by herself. }\end{array}$ & P-P 4 & & & \\
\hline & $\begin{array}{l}\text { I think yes, somehow, she learned because she's } \\
\text { able to answer her module without asking help. }\end{array}$ & P-P 5 & & & \\
\hline
\end{tabular}

(C) 2021 EPRA IJRD | Journal DOI: https://doi.org/10.36713/epra2016 | www.eprajournals.com |289 | 


\section{EPRA International Journal of Research and Development (IJRD) \\ Volume: 6 | Issue: 6 | June 2021 \\ - Peer Reviewed Journal}

Based on the responses given, it may conclude that some of the ways/ strategies that parents do in guiding the learners in answering the modules include Constant Reminding of Deadlines as guide for learners to finish the modules, explaining to the learner the parts of the modules which are not clear (tutoring), and giving of Time Allotment to properly finish the task. From these responses, the theme shows that parents' role are facilitators of learning. Also, from the responses, learners are learning, imposing that there is effectiveness in implementing Modular Distance Learning.

Table 8. Strategies used by Learners to Finish in Answering Modules

\begin{tabular}{|c|c|c|c|c|c|}
\hline \multirow[t]{2}{*}{ QUESTIONS } & \multirow[t]{2}{*}{ RAW DATA (RESPONSES/ANSWERS) } & \multirow{2}{*}{$\begin{array}{c}\text { PARTI } \\
\text { CIPAN } \\
\text { TS }\end{array}$} & \multicolumn{2}{|c|}{ PRELIMINARY CODES } & \multirow[t]{2}{*}{ THEMES } \\
\hline & & & $\begin{array}{l}\text { COMMONAL } \\
\text { ITIES }\end{array}$ & $\begin{array}{l}\text { CATEG } \\
\text { ORIES }\end{array}$ & \\
\hline \multirow{5}{*}{$\begin{array}{l}\text { 3.3. How do } \\
\text { you } \\
\text { motivate } \\
\text { yourself to } \\
\text { accomplish } \\
\text { all the } \\
\text { tasks? Can } \\
\text { you tell me } \\
\text { more? }\end{array}$} & $\begin{array}{l}\text { I just think that I am graduating student, I just } \\
\text { tell myself that if others can do it so can I. }\end{array}$ & S-P 1 & \multirow{5}{*}{\multicolumn{2}{|c|}{ The Learning Process }} & \multirow{5}{*}{$\begin{array}{l}\text { Learner's } \\
\text { Percepti } \\
\text { ons on } \\
\text { MDL }\end{array}$} \\
\hline & $\begin{array}{l}\text { I just think that it will end as well, we can also } \\
\text { ask the help of teachers. }\end{array}$ & S-P 2 & & & \\
\hline & $\begin{array}{l}\text { If I cannot answer the lesson, I'll read it again, } \\
\text { then I'll skip it. I'll answer first the task that is } \\
\text { easy for me, when I'm done all the tasks I'll go } \\
\text { back to the difficult task. }\end{array}$ & S-P 3 & & & \\
\hline & $\begin{array}{l}\text { I just think that I can answer all the task I } \\
\text { don't take it as a negative side. }\end{array}$ & S-P 4 & & & \\
\hline & $\begin{array}{l}\text { I motivate myself by thinking that it is only a } \\
\text { trial, sometimes I ask the help of my classmate } \\
\text { so that I can have some idea or I'm using the } \\
\text { internet. }\end{array}$ & S-P 5 & & & \\
\hline \multirow{5}{*}{$\begin{array}{l}\text { 4. Can you } \\
\text { tell me that } \\
\text { you are } \\
\text { learning } \\
\text { from these } \\
\text { self-leaning } \\
\text { modules? } \\
\text { Why do you } \\
\text { say so? }\end{array}$} & $\begin{array}{l}\text { Yes, because through reading there is } \\
\text { something I understand }\end{array}$ & S-P 1 & \multirow{5}{*}{\multicolumn{2}{|c|}{$\begin{array}{l}\text { Challenges to the } \\
\text { Learning Process }\end{array}$}} & \multirow{5}{*}{$\begin{array}{l}\text { Learner's } \\
\text { Percepti } \\
\text { ons on } \\
\text { MDL }\end{array}$} \\
\hline & $\begin{array}{l}\text { Yes, because it is written in the module the } \\
\text { things that we need to learn }\end{array}$ & S-P 2 & & & \\
\hline & $\begin{array}{l}\text { Somehow, because my understanding are not } \\
\text { that wide to understand the lesson. }\end{array}$ & S-P 3 & & & \\
\hline & $\begin{array}{l}\text { Yes, because my English vocabulary are } \\
\text { enhanced through reading }\end{array}$ & S-P 4 & & & \\
\hline & $\begin{array}{l}\text { For me yes, because I become independent in } \\
\text { understanding the lesson }\end{array}$ & S-P 5 & & & \\
\hline
\end{tabular}

From the responses given, it may be inferred that there is "intrinsic motivation" in the learners that drives them to finish the different tasks on the module. Based on their responses, it shows that they set their minds to finish the task even if it is hard because eventually, they will be able to finish that. Another Strategy that was mentioned is that they know how to filter the tasks from easy to difficult. They try to answer modules with tasks that is easy to do, and the difficult tasks were done in the latter part to save time in answering the modules. The category falls on the learning process where their "intrinsic motivation" drives them to finish the tasks in the modules. 


\section{EPRA International Journal of Research and Development (IJRD)}

Challenges Encountered by the Parents and Learner

Table 9. Challenges Encountered by the Parents

\begin{tabular}{|c|c|c|c|c|c|}
\hline \multirow[t]{2}{*}{ QUESTIONS } & \multirow[t]{2}{*}{ RAW DATA (RESPONSES/ANSWERS) } & \multirow{2}{*}{$\begin{array}{l}\text { PARTI } \\
\text { CIPAN } \\
\text { TS }\end{array}$} & \multicolumn{2}{|c|}{$\begin{array}{l}\text { PRELIMINARY } \\
\text { CODES }\end{array}$} & \multirow[t]{2}{*}{ THEMES } \\
\hline & & & $\begin{array}{l}\text { COMMON } \\
\text { ALITIES }\end{array}$ & $\begin{array}{l}\text { CATEG } \\
\text { ORIES }\end{array}$ & \\
\hline \multirow{5}{*}{$\begin{array}{l}\text { 3.2. Are there } \\
\text { times that you } \\
\text { observed that } \\
\text { you are having } \\
\text { a hard times } \\
\text { and difficulties } \\
\text { in answering } \\
\text { the entire } \\
\text { learning task? }\end{array}$} & Not really, because she loves to study & P-P 1 & \multirow{5}{*}{\multicolumn{2}{|c|}{$\begin{array}{l}\text { Monitoring of } \\
\text { Learning Tasks } \\
\text { (at home) }\end{array}$}} & \multirow{5}{*}{$\begin{array}{c}\text { Parents } \\
\text { as PARA- } \\
\text { TEACHE } \\
\text { RS } \\
\text { (facilitati } \\
\text { ng } \\
\text { learning) }\end{array}$} \\
\hline & $\begin{array}{l}\text { Yes, but with the help of parents and } \\
\text { internet she is able to answer the task. }\end{array}$ & P-P 2 & & & \\
\hline & Yes, because sometimes she is very moody. & P-P 3 & & & \\
\hline & Yes, there is & P-P 4 & & & \\
\hline & Yes & P-P 5 & & & \\
\hline \multirow{5}{*}{$\begin{array}{l}\text { 4.1. Based on } \\
\text { your own } \\
\text { observation, are } \\
\text { these SLMs itself } \\
\text { are enough to } \\
\text { provide you } \\
\text { quality } \\
\text { education? Why } \\
\text { do you say so? }\end{array}$} & $\begin{array}{l}\text { If you think of it face to face is better but } \\
\text { because of the pandemic we must be like } \\
\text { this. }\end{array}$ & P-P 1 & \multirow{5}{*}{\multicolumn{2}{|c|}{ MDL's Challenges }} & \multirow{5}{*}{$\begin{array}{c}\text { Parents } \\
\text { as PARA- } \\
\text { TEACHE } \\
\text { RS } \\
\text { (facilitati } \\
\text { ng } \\
\text { learning) }\end{array}$} \\
\hline & $\begin{array}{l}\text { Ma'am maybe not, we cannot tell right now } \\
\text { because it takes time to tell how effective } \\
\text { these processes are. }\end{array}$ & P-P 2 & & & \\
\hline & No, face to face is better & P-P 3 & & & \\
\hline & $\begin{array}{l}\text { No, I think face to face is better students } \\
\text { need a teacher to explain and answer the } \\
\text { question of the students. }\end{array}$ & P-P 4 & & & \\
\hline & $\begin{array}{l}\text { No, it is much better that there is a teacher } \\
\text { who teach them. }\end{array}$ & P-P 5 & & & \\
\hline \multirow{5}{*}{$\begin{array}{l}\text { 5. As a parent, } \\
\text { what are the } \\
\text { challenges of } \\
\text { this modular } \\
\text { distance } \\
\text { learning? }\end{array}$} & $\begin{array}{l}\text { I will just let my daughter to answer the } \\
\text { task because she can handle it. }\end{array}$ & P-P 1 & \multirow{5}{*}{\multicolumn{2}{|c|}{ MDL's Challenges }} & \multirow{5}{*}{$\begin{array}{c}\text { Parents } \\
\text { as PARA- } \\
\text { TEACHE } \\
\text { RS } \\
\text { (facilitati } \\
\text { ng } \\
\text { learning) }\end{array}$} \\
\hline & Very hard & P-P 2 & & & \\
\hline & $\begin{array}{l}\text { As guardian, what really hard is that when } \\
\text { she ask you a question and you don't know } \\
\text { the answer especially those who have not } \\
\text { studied. }\end{array}$ & P-P 3 & & & \\
\hline & $\begin{array}{l}\text { It's hard to understand the lesson all by } \\
\text { yourself. }\end{array}$ & P-P 4 & & & \\
\hline & Nothing & P-P 5 & & & \\
\hline \multirow{5}{*}{$\begin{array}{c}\text { 5.1. Can you } \\
\text { identify some? } \\
\text { Please } \\
\text { elaborate }\end{array}$} & $\begin{array}{l}\text { My daughter answers the task all by herself } \\
\text { since she can handle it. }\end{array}$ & P-P 1 & \multirow{5}{*}{\multicolumn{2}{|c|}{$\begin{array}{l}\text { "Teacher's cannot } \\
\text { be replace by this } \\
\text { learning modality" }\end{array}$}} & \multirow{5}{*}{$\begin{array}{c}\text { Parents } \\
\text { as PARA- } \\
\text { TEACHE } \\
\text { RS } \\
\text { (facilitati } \\
\text { ng } \\
\text { learning) }\end{array}$} \\
\hline & $\begin{array}{l}\text { Communication with the teacher, student's } \\
\text { questions cannot answer immediately. }\end{array}$ & P-P 2 & & & \\
\hline & $\begin{array}{l}\text { Sometimes there is no internet connection } \\
\text { or even load that's the difficulty. }\end{array}$ & P-P 3 & & & \\
\hline & It is hard if there is no teacher to guide you & P-P 4 & & & \\
\hline & $\begin{array}{l}\text { It's just as difficult as when in the news the } \\
\text { student thought of committing suicide. }\end{array}$ & P-P 5 & & & \\
\hline
\end{tabular}

From the responses given, it may be inferred that even the parents as the one who guides the learners in the modular distance learning also experiences challenges and difficulties. One of the challenges mentioned was the communication with the teacher. If a student has questions o the teacher, it takes some time for the teacher to answer the query of the learners since they are many to be entertained one by one by the teacher. Another challenge that was mentioned is that the limited knowledge of the parent on a certain topic in the lesson. Since not all parents was able to finish their studies, some parents are not familiar with the lesson, so it becomes difficult for the learners to understand more the lesson in answering the tasks in the module.' 


\section{EPRA International Journal of Research and Development (IJRD)}

\begin{tabular}{|c|c|c|c|c|c|}
\hline \multirow[b]{2}{*}{ QUESTIONS } & \multirow[b]{2}{*}{ RAW DATA (RESPONSES/ANSWERS) } & \multirow[b]{2}{*}{$\begin{array}{l}\text { PART } \\
\text { ICIPA } \\
\text { NTS }\end{array}$} & \multicolumn{2}{|c|}{ PRELIMINARY CODES } & \multirow[b]{2}{*}{ THEMES } \\
\hline & & & $\begin{array}{l}\text { COMMONAL } \\
\text { ITIES }\end{array}$ & $\begin{array}{l}\text { CATEG } \\
\text { ORIES }\end{array}$ & \\
\hline \multirow{5}{*}{$\begin{array}{l}\text { 3.2. Are there } \\
\text { times that } \\
\text { you observed } \\
\text { that you are } \\
\text { having a hard } \\
\text { times and } \\
\text { difficulties in } \\
\text { answering } \\
\text { the entire } \\
\text { learning } \\
\text { task? }\end{array}$} & $\begin{array}{l}\text { Yes. When I don't have data to ask questions to my } \\
\text { teacher and there are times that I can't watch the } \\
\text { videos because I do not have internet or data. }\end{array}$ & S-P 1 & \multirow{5}{*}{\multicolumn{2}{|c|}{$\begin{array}{l}\text { Challenges to diverse } \\
\text { learners }\end{array}$}} & \multirow{5}{*}{$\begin{array}{c}\text { Learner's } \\
\text { Perceptio } \\
\text { ns on } \\
\text { MDL }\end{array}$} \\
\hline & $\begin{array}{l}\text { Yes, I am not that good at understanding everything. } \\
\text { But those videos that they provide in the modules, I } \\
\text { watch it repeatedly so I can understand the lesson. }\end{array}$ & S-P 2 & & & \\
\hline & $\begin{array}{l}\text { Yes. I find difficulties when no can asked at home, } \\
\text { because mom and dad have to go to work. So I can't } \\
\text { follow the WHLP. }\end{array}$ & S-P 3 & & & \\
\hline & $\begin{array}{l}\text { Yes, especially when the lesson are hard to } \\
\text { understand. }\end{array}$ & S-P 4 & & & \\
\hline & Yes. & S-P 5 & & & \\
\hline \multirow{5}{*}{$\begin{array}{l}\text { 4.1. Based on } \\
\text { your own } \\
\text { observation, } \\
\text { are these } \\
\text { SLMs itself } \\
\text { are enough } \\
\text { to provide } \\
\text { you quality } \\
\text { education? } \\
\text { Why do you } \\
\text { say so? }\end{array}$} & $\begin{array}{l}\text { No, face to face is better, there is a teacher who will } \\
\text { teach us compare to self-study, if there is a teacher we } \\
\text { understand better. }\end{array}$ & S-P 1 & \multirow{5}{*}{\multicolumn{2}{|c|}{$\begin{array}{l}\text { Evaluation of } \\
\text { Learning through } \\
\text { MDL }\end{array}$}} & \multirow{5}{*}{$\begin{array}{c}\text { Learner's } \\
\text { Perceptio } \\
\text { ns on } \\
\text { MDL }\end{array}$} \\
\hline & $\begin{array}{l}\text { No, we are not used to in this kind of situation that is } \\
\text { why there some students who are struggling. }\end{array}$ & S-P 2 & & & \\
\hline & $\begin{array}{l}\text { Yes, because there are students learned by studying } \\
\text { their activities. }\end{array}$ & S-P 3 & & & \\
\hline & For me no, face to face is better. & S-P 4 & & & \\
\hline & $\begin{array}{l}\text { For me no, face to face is better because there are } \\
\text { communication between teacher and student, they } \\
\text { can give you example they explained well. }\end{array}$ & S-P 5 & & & \\
\hline \multirow{5}{*}{$\begin{array}{c}\text { 5. As a } \\
\text { parent, what } \\
\text { are the } \\
\text { challenges of } \\
\text { this modular } \\
\text { distance } \\
\text { learning? }\end{array}$} & Very hard & S-P 1 & \multirow{5}{*}{\multicolumn{2}{|c|}{$\begin{array}{l}\text { Challenges to the } \\
\text { Learning Process }\end{array}$}} & \multirow{5}{*}{$\begin{array}{c}\text { Learner's } \\
\text { Perceptio } \\
\text { ns on } \\
\text { MDL }\end{array}$} \\
\hline & Time management & S-P 2 & & & \\
\hline & Understanding the lesson & S-P 3 & & & \\
\hline & $\begin{array}{l}\text { Like what I said, challenge for me is without asking } \\
\text { the help of others }\end{array}$ & S-P 4 & & & \\
\hline & The challenge I experienced is to become independent & S-P 5 & & & \\
\hline \multirow{5}{*}{$\begin{array}{l}\text { 5.1. Can you } \\
\text { identify } \\
\text { some? Please } \\
\text { elaborate }\end{array}$} & $\begin{array}{l}\text { When I ask my parents they do not know the answer, } \\
\text { sometimes it is hard to ask question unlike face to face } \\
\text { setting the teacher can explain those and that.... }\end{array}$ & S-P 1 & \multirow{5}{*}{\multicolumn{2}{|c|}{$\begin{array}{l}\text { Evaluation of } \\
\text { Learning through } \\
\text { MDL }\end{array}$}} & \multirow{5}{*}{$\begin{array}{c}\text { Learner's } \\
\text { Perceptio } \\
\text { ns on } \\
\text { MDL }\end{array}$} \\
\hline & $\begin{array}{l}\text { For me we need time management to accomplish the } \\
\text { activities, if you do not know the answer it is also hard } \\
\text { to communicate with the teacher. }\end{array}$ & S-P 2 & & & \\
\hline & Time management because of household chores. & S-P 3 & & & \\
\hline & $\begin{array}{l}\text { If you have question no teacher can answer you } \\
\text { immediately, I don't if what I know is right }\end{array}$ & S-P 4 & & & \\
\hline & Sometimes it is hard to understand the lesson & S-P 5 & & & \\
\hline
\end{tabular}

Table 10. Challenges Encountered by the Learners

All the responses of the learners fall on the category that these are challenges to the diverse learners and a challenge in the learning process of a student in implementing the Modular Distance Learning Modality as Contemporary Teaching Strategy.

\section{Proposed Learning Intervention}

After the presentation, interpretation and thorough analysis of the data gathered from the interview done to Parent-Participants and StudentParticipants, it poses that there are advantages and disadvantages on the implementation of Modular Distance Learning as Contemporary Teaching Strategy 


\section{EPRA International Journal of Research and Development (IJRD) \\ Volume: 6 | Issue: 6 | June 2021 \\ - Peer Reviewed Journal}

as based on the different perceptions gathered from the respondents.
From this, the researcher proposes an intervention program based on the results of the research.

Table 11. Proposed Intervention (Action Plan)

\begin{tabular}{|c|c|c|c|c|c|}
\hline \multirow[t]{2}{*}{$\begin{array}{c}\text { AREA(S) } \\
\text { And Project Title }\end{array}$} & \multirow[t]{2}{*}{ OBJECTIVES } & \multirow[t]{2}{*}{$\begin{array}{c}\text { PERSON(S) } \\
\text { RESPONSIBLE }\end{array}$} & \multirow[t]{2}{*}{ TIME FRAME } & \multicolumn{2}{|c|}{$\begin{array}{l}\text { RESOURCES } \\
\text { NEEDED/SOURCE OF } \\
\text { FUND }\end{array}$} \\
\hline & & & & $\begin{array}{c}\text { Equipment / } \\
\text { Material } \\
\text { Needed } \\
\end{array}$ & $\begin{array}{l}\text { Source of } \\
\text { Fund }\end{array}$ \\
\hline $\begin{array}{l}\text { Modyul mo, Hatid } \\
\text { ko! }\end{array}$ & $\begin{array}{l}\text { To deliver Learning } \\
\text { Packets with the aid } \\
\text { of community } \\
\text { partners (Team } \\
\text { Mayabo, Liga ng mga } \\
\text { Baranggay). }\end{array}$ & $\begin{array}{l}\text { Teachers } \\
\text { Team Mayabo } \\
\text { (association of } \\
\text { riders) } \\
\text { Liga ng mga } \\
\text { Baranggay }\end{array}$ & Oct - July 2021 & $\begin{array}{l}\text { Students } \\
\text { Learning } \\
\text { Packets }\end{array}$ & MOOE \\
\hline $\begin{array}{l}\text { Project Bente Mo } \\
\text { - Kinabukasan } \\
\text { ko! }\end{array}$ & $\begin{array}{l}\text { To raise fund for } \\
\text { learners' kit and to } \\
\text { buy additional school } \\
\text { supply like bond } \\
\text { papers for printing of } \\
\text { activity sheets. }\end{array}$ & $\begin{array}{l}\text { Parents } \\
\text { Teachers } \\
\text { Association }\end{array}$ & Oct.- July 2021 & $\begin{array}{l}\text { Ads through } \\
\text { platforms }\end{array}$ & \\
\hline Project Reach & $\begin{array}{l}\text {-To establish } \\
\text { connection between } \\
\text { the school and home } \\
\text { to develop, enhance } \\
\text { the reading skills of } \\
\text { the learners. } \\
\text {-To empower parents } \\
\text { and guardians in } \\
\text { assisting their } \\
\text { children to read at a } \\
\text { regular scheduled } \\
\text { time. } \\
\text {-Provide children } \\
\text { reading materials } \\
\text { that will help them to } \\
\text { be empowered } \\
\text { readers by } \\
\text { developing their } \\
\text { vocabulary, study } \\
\text { skills, media literacy } \\
\text { and reading } \\
\text { comprehension skills. }\end{array}$ & $\begin{array}{l}\text { English Teachers } \\
\text { Class Adviser }\end{array}$ & $\begin{array}{l}\text { Full } \\
\text { Implementati } \\
\text { on } \\
\text { SY 2021-July } \\
2022 \\
\\
\text { Pilot } \\
\text { Implementati } \\
\text { on March } \\
2021 \text { July } \\
2021 \quad \\
\text { Planning } \\
\text { Preparation } \\
\text { January - } \\
\text { February } \\
\text { 2021 }\end{array}$ & $\begin{array}{l}\text { Reading } \\
\text { materials }\end{array}$ & MOOE \\
\hline
\end{tabular}

(c) 2021 EPRA IJRD | Journal DOI: https://doi.org/10.36713/epra2016 | www.eprajournals.com |293 | 
Table 12. Proposed Intervention Program for Parents/ Guardians

\begin{tabular}{|l|l|c|c|}
\hline \multicolumn{1}{|c|}{ PROGRAM } & \multicolumn{1}{|c|}{ OBJECTIVES } & \multicolumn{1}{c|}{$\begin{array}{c}\text { PERSON(S) } \\
\text { RESPONSIBLE }\end{array}$} & TIME FRAME \\
\hline $\begin{array}{l}\text { Virtual Kumustahan } \\
\text { on a weekly basis }\end{array}$ & $\begin{array}{l}\text { The purpose of this } \\
\text { activity is to reach } \\
\text { parents/ guardians } \\
\text { virtually. Its aim is to } \\
\text { address some issues and } \\
\text { answer the parents/ } \\
\text { guardian concerns } \\
\text { regarding the lessons. }\end{array}$ & $\begin{array}{c}\text { Parents/ guardians } \\
\text { teacher }\end{array}$ & Whole school year \\
\hline Facebook Group & $\begin{array}{l}\text { This platform serve as a } \\
\text { venue for parents and } \\
\text { teacher to reconnect and } \\
\text { to update each other in } \\
\text { the activities regarding } \\
\text { the lesson despite the } \\
\text { pandemic. }\end{array}$ & $\begin{array}{c}\text { Parents/ guardians } \\
\text { teacher }\end{array}$ & Whole school year \\
\hline Video clips & $\begin{array}{l}\text { The purpose of this } \\
\text { activity is to assist the } \\
\text { parents and students in } \\
\text { answering the lesson, } \\
\text { giving them further } \\
\text { explanation and } \\
\text { instruction for better } \\
\text { understanding and } \\
\text { interaction. }\end{array}$ & $\begin{array}{c}\text { Parents/ guardians } \\
\text { Teacher } \\
\text { students }\end{array}$ & Whole school year \\
\hline
\end{tabular}

\section{CONCLUSION}

Based on the results of the qualitative inquiry, the researcher has drawn the following conclusions:

1. The Perception of Parents and Learners on Modular Distance learning as contemporary teaching strategy shows effectiveness even facing different challenges and disadvantage.

2. Challenges that Parents and Students encounter such as the time management, limited knowledge of the parents on the topics in the modules, independence in learning, access to other resources for learning should be given attention and solution to improve more the implementation of the Modular Distance Learning.

3. Intervention programs should be administered to support and enhance the current situation of
Distance Learning Modality to improve more the teaching and learning process in this contemporary teaching.

\section{Recommendation}

Based on the findings and formulated conclusions, the following are highly recommended:

1. School may implement the proposed intervention program through the Action Plan as support for the delivery of learning to all the learners.

2. The school may strengthen the partnership with its stakeholders through continuous communication. It is important that in implementing various Distance Learning Modality, there should still be strong partnership with the learners, parent, and 


\section{EPRA International Journal of Research and Development (IJRD) \\ Volume: 6 | Issue: 6 | June 2021 \\ - Peer Reviewed Journal}

community for a successful implementation of learning modalities in the New Contemporary Teaching.

3. Learners and Parents may establish more communication in different means to assure continues monitoring and support on the teaching-learning process of the students.

\section{REFERENCES}

1. Aggabao, Ambrose Hans. Development and Evaluation of Individualized Self Instructional Modules on Selected Topics in Basic Mathematics. (Journal of Research, Isabela State University, Vol. XI, No. 1, January - December 2012).

2. Akinoglu ., O. and Tandogan., R. (2016). The effect of Problem based active learning in science education on student's academic achievement, attitude, and concept learning. Eurasia journal of mathematics, science and technology education, 3(1), 7181.

3. Amedzro, K.A.D. (2005). Theory and practice of adult education. Accra: Ghana University Press.

4. Amponsah, S. (2010). The evolution and implementation strategies of the University of Ghana Bachelor of Arts distance education programme. Unpublished M.Phil. Thesis. University of Ghana.

5. Aquino-Danganan, Aussie. (2011) "Development and Validation of A Module in Developing Computational Skills in College Algebra" Unpublished Thesis, Tarlac State University

6. Bevan, M. T. (2014). A method of phenomenological interviewing. Qualitative Health Research.

7. Biggs, J. (2010). Teaching for Quality Learning at University. Buckingham: SRHE/OU Press

8. Cappetta, Robert W., 2007, Reflective Abstraction and the Concept of Limit: A Quasi-Experimental Study to Improve Student Performance in College Calculus by Promoting Reflective Abstraction through Individual, Peer, Instructor and Curriculum Initiates, (Dissertation Abstract International Vol. 69 No. 2 August (541-A)

9. Cardon, P. (2015). At risk students and technology education. The Journal of Technology Studies, 26(1), 49-57.

10. Commonwealth of Learning (2005), Planning Open and Distance Learning Systems: A Handbook for Decision Makers. Vancouver: Commonwealth of Learning. Retrieved from http://www.saide.org.zal sites/default/files/course_design/odlinstdesignHB.p $d f$

11. Department of Education, Philippines (2020). DepEd Memorandum (DM) No. 15, 21, 23, 31 and 34 series of 2020. "Creation of a Task Force for the Management of Department of Education Response to Novel Coronavirus Acute Respiratory Disease (2019-nCoV ARD)"
4. Include the parents/ guardians in conducting School Learning Action Cell since they are the one who guide their son/ daughter in explaining the lesson amidst pandemic.

12. Delgado, Ana J., 2016, Effects of the Use of Computers, Integrated to an Instructional Module on Functions of the Attitudes towards Mathematics and the Achievement in Functions in Precalculus of College Students, (Dissertation Abstract International Vol. 67 No. 6 December (2084-A).

13. Dewey, J. (1933). How we think. (pp, 133-219). Lexington, MA: D.C. Heath and Company.

14. Evasco, N. B. (2020). Sta. Catalina Integrated National High School's Learning Continuity Plan for School Year 2020-2021

15. Gagarin, C. (2013). Module in physics I: Development and Evaluation (Master's thesis). Eulogio "Amang "Rodriguez Institute of Science and Technology, Manila.

16. Ghabanchi., Z. and Behrooznia., S. (2016).The impact of brainstorming on reading comprehension and critical thinking ability of EFL Learners. Social and Behavioral Science, (98). 513 521. DOI. 10.1016

17. Guimbatan A. (2013) Educational Alternatives. Mandaluyong City, Philippines: Academic Publishing Corporation, 2013

18. Guo, Y., Cao, Q., (2020). The origin, transmission and clinical therapies on coronavirus disease 2019 (COVID-19) outbreak - an update on the status. Military Med Res, 7(11). https://doi.org/10.1186/s40779-020-00240-0

19. Hermosisima, $V$. (2019). Development and Validation of Modules in Physics 112 (Magnetism) for DTI Students of Cebu State College of Science and Technology (Unpublished Master's Thesis). Philippine Normal University, Manila.

20. Kemp, O. and Smelie, A. (2019) Planning, Producing and Using Instructional Media, New York: Harper \& Row Publishing

21. Kidd, A. (2012). The oxford union rough guide to debating. The English Speaking Union. Retrieved from:

http://www.britishdebate.com/resources/hb_html

22. Lacdao, Melchor O. (2014) "A Comparative Study of the Effects of Modular Instruction and Lecture Discussion Method on the Achievement of Grade Six Pupils in Mathematics" Unpublished Master's Thesis, Eastern Samar State College, Borongan, Eastern Samar.

23. LeBrun, D. (2015). A Study of Modularized Instructions And Its Role In TheTechnology Education Curriculum At Southern Door Schools University of Wisconsin-Stout. 


\section{SJIF Impact Factor 2021: 8.013| ISI I.F.Value:1.241| Journal DOI: 10.36713/epra2016 ISSN: 2455-7838(Online) \\ EPRA International Journal of Research and Development (IJRD)}

Volume: 6 | Issue: 6 | June 2021

- Peer Reviewed Journal

24. Madriaga, Estelita A. (2014) "Effects of Modular Instruction in Teaching Physics", Unpublished Master's Thesis, Samar State Polytechnic College, Catbalogan Samar

25. Morse, J. M., et. al. (2002). Verification strategies for establishing reliability and validity in qualitative research. International Journal for Qualitative methods.

26. Okon., C. (2014). Teachers attitude to social studies and students academic performance in junior secondary Three certificate examination through Modular Learning. Asian Journal of Social Science and Humanities, 3(3), 1217.

27. Olweus, D. (1993). Annotation: Bullying at school: Basic facts and effects of aschool based intervention program. Journal of Child Psychology \& Psychiatry \& Allied Disciplines, 35(7), 11711190.

28. Onwuegbuzie, A. J., \& Collins, K. M. T. (2007). A typology of mixed methods sampling designs in Social Science research. The Qualitative Report. Retrieved from https://nsuworks.nova.edu/cgi/viewcontent.cgi?arti cle $=1638 \&$ context $=$ tqr

29. Patton, M. Q. (2015). Qualitative Research and Evaluation Methods (3rd Edition)

30. Palinkas, L. A., et. al. (2015). Purposeful sampling for qualitative data collection and analysis in mixed method implementation

31. Race, Phil. (2019) The Open Learning Handbook. USA: Nichols Publishing

32. Receno, Carmela N. (2011) "Development of Instructional Materials for the Enhancement of the Listening Skills among Freshman College Students of SMCL" Unpublished Thesis Philippine Normal University

33. Rizaldo, Rosita, et. al., (2017) Comparative Effects of Modular and Traditional Methods in Teaching Analytic Geometry (A Publication of Research \& Educational Development Training Institute, Vol 6).

34. Rossman, G. B., \& Rallis, S. F. (1998). Learning in the field: An introduction to qualitative research. Thousand Oaks, CA: Sage.

35. Rudnitsky, A. N. (2011). Course Design: A Guide to Curriculum Development for Teachers. New York: Longman

36. Salandanan, Gloria G. (2011) Teaching and the Teacher, Quezon City: Adriana Printing Co., Inc

37. Salandanan Gloria G. (2019) Teacher Education. QC, KATHA Publishing Co., Inc.

38. Sadsad, Z. (2011). Validity of the Resource Book in Science I (Master'sThesis). Eulogio “Amang "Rodriguez Institute of Science and Technology, Manila.

39. Sejpal, K.(2013). Learning and skill network Independent learning literature review (Vol. 2, Issue: 2, February 2013 (IJRE) ISSN:2320-091X pp. 170
40. Simpson, O. (2013). Student retention in distance education: are we failing our students? Open Learning: The Journal of Open, Distance and eLearning, 28(2), 105-119. Retrieved from http://www.tandfonline.com/ doi/full/10.1080/02680513.2013.847363

41. Taneja, R. (2014). Dictionary of Education. Anmol Publication Murare New Dehli, India p. 155

42. Vega, J. (2014). Computer-Bbased Modules in Selected Topics for Drafting (Master's thesis). Eulogio "Amang "Rodriguez Institute of Science and Technology, Manila.

43. Vaismoradi, M. et. al. (2016). Theme development in qualitative content analysis and thematic analysis. Journal of Nursing Education and Practice.

44. Woolfolk, A. E., (2010) Educational Psychology. Massachusetts: Allyn \& Bacon Publishing

45. Wilkerson, V. L. (2017). A Guide To Teaching With Modules Hope College

46. Zare., P. and Othman., M. (2013). Classroom debate as systematic learning and teaching approach. Journal of World Applied Science, 28 (11) 150

47. Zulueta, Francisco (2013) Teaching Strategies \& Educational Alternatives. Vol. 1, Mandaluyong City, Philippines: Academic Publishing Corporation, 2013 (57-59) 